\title{
Studies on Dietary Correction of Metabolic Abnormalities in Hepatorenal Glycogenosis ${ }^{[5]}$
}

\author{
Robert C. KeLsGh ${ }^{[48]}$ and William J. Olrver \\ Department of Pediatrics and Communicable Diseases, University of Michigan Medical School, \\ Ann Arbor, Michigan, USA
}

\begin{abstract}
Extract
This study reports the effects of frequent glucose feeding on the metabolic abnormalities observed in a patient with hepatorenal glycogenosis. Use of this diet resulted in correction of metabolic acidosis and hyperlacticacidemia. External calcium balance became positive secondary to a decrease in the loss of calcium in urine. Long-term use of the diet caused a reduction to normal values of triglyceride and cholesterol levels in serum. Continued use of the diet for nine months resulted in increased growth rate and increased calcification of bone. Evidence based on excretion of epinephrine and 17-hydroxycorticosteroids in urine did not indicate that an increased excretion of these hormones occurred in response to hypoglycemia. Concentrations of growth hormone were low despite hypoglycemia; however, after nine months of treatment, the patient showed a rapid decline in the levels of blood sugar with an increase in the levels of growth hormone in blood.
\end{abstract}

\section{Speculation}

Partially controlled hepatorenal glycogenosis is in some ways similar to juvenile diabetes mellitus since patients with this disease sustain intermittent starvation of the peripheral tissues for glucose. Study of the metabolic sequellae of peripheral glucose deprivation and repletion in some forms of glycogenosis may lead to a better understanding of the complications of juvenile diabetes mellitus.

\section{Introduction}

The major metabolic sequellae of hepatorenal glycogenosis (HRG) are considered to be secondary to an inability of the liver lacking glucose-6-phosphatase activity to supply the need of peripheral tissues for glucose [20]. Frequent glucose feeding is generally considered to be the most effective treatment for this form of glycogen storage disease $[6,22,37]$. Short-term observations support this conviction [20,21, 22, 30], but there are few published data describing the longterm effectiveness of this therapy. This study attempted to evaluate the initial and long-term effects of glucose feeding on the hyperlacticacidemia, hyperuricemia, and metabolic acidosis associated with this disease. Balances of external calcium and phosphorus were measured during initial treatment to determine whether excessive urinary loss or defective absorption of calcium [9] lead to the osteoporosis and pathologic fractures observed. Because the patient exhibited growth failure, osteoporosis, and serum lipid abnormalities, the responses to the dietary program of plasma growth hormone, adrenal steriod production, and catecholamine excretion were evaluated. An improved growth rate followed institution of dietary therapy for nine months. 


\section{Case Report}

A $91 \frac{1}{2}$-year-old Caucasian boy was first admitted to the University of Michigan Medical Center at 19 months of age for evaluation of an enlarged liver. Abdominal enlargement was noticed by his parents at six months of age. Past history documented the occurrence of numerous unexplained convulsions during the first week of life and poor weight gain after six monthsof age.

Physical examination showed a thin child with a massively enlarged abdomen. Height and weight were $81 \mathrm{~cm}$ and $10.9 \mathrm{~kg}$, respectively. The liver was palpable at the iliac crest. The following laboratory studies in blood were obtained: $\mathrm{pH}, 7.25$; total $\mathrm{CO}_{2}, 12 \mathrm{~mm} / 1$; fasting sugar (Somogyi-Nelson), $20 \mathrm{mg} / 100 \mathrm{ml}$; BUN, $14 \mathrm{mg} / 100 \mathrm{ml}$; total lipids, $1.8 \mathrm{~g} / 100 \mathrm{ml}$. An epinephrine stimulation test $(0.1 \mathrm{ml}$ of $1: 1000$ epinephrine injected subcutaneously) gave the following results: pre-injection for glucose, $11 \mathrm{mg} / 100 \mathrm{ml} ; 15$ minutes, $5 \mathrm{mg} / 100$ $\mathrm{ml} ; 30$ minutes, $10 \mathrm{mg} / 100 \mathrm{ml} ; 45$ minutes, $11 \mathrm{mg} /$ $100 \mathrm{ml}$. A significant ketonuria was present. X-ray examinations showed bilaterally enlarged kidneys and demineralization of the distal femurs. A diagnosis of glycogen storage disease was made and the patient was discharged. The parents were instructed to provide a high protein diet to be offered frequently. Sodium bicarbonate to be administered by mouth was prescribed to ameliorate metabolic acidosis.

During the following eight years he was admitted frequently for treatment of metabolic acidosis precipitated by respiratory infections. Epistaxes were common; on two occasions these were sufficiently severe to require blood transfusions. During this interval he sustained three fractures with minimal trauma; roentgenograms consistently showed poor mineralization of bones. At nine years of age, the patient developed hematuria. Intravenous pyelograms showed symetrically enlarged kidneys and a partially calcified calculus in the middle calyx of the right kidney. Throughout this period the patient had progressed normally in school, performing above average in the fourth grade. Height had remained below the 3rd percentile. Episodes consistent with hypoglycemia were rare.

\section{Family History}

The parents were of Caucasian descent and unrelated. There were two siblings, a seven-year-old sister who was apparently well and a two-year-old sister who had HRG. The latter had exhibited skeletal demineralization and had sustained three fractures the preceding year.

\section{Present Admission}

On admission, the patient appeared alert and in no distress, though obviously hyperpneic. Height and
Table I $a$. Intravenous galactose ${ }^{1}$ tolerance test

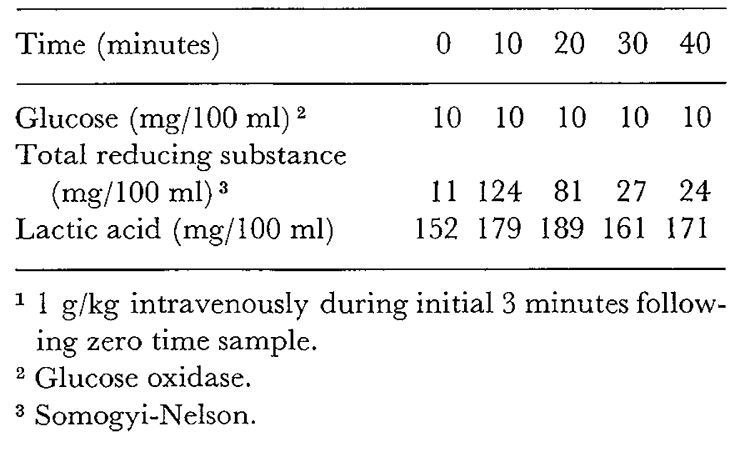

Table $I b$. Glucagon ${ }^{1}$ stimulation test (2 hours postprandial)

\begin{tabular}{lcccccc}
\hline Time (minutes) & 0 & 10 & 20 & 30 & 40 & 60 \\
\hline Glucose $(\mathrm{mg} / 100 \mathrm{ml})$ & 46 & 40 & 38 & 36 & 34 & 30 \\
Lactic acid $(\mathrm{mg} / 100 \mathrm{ml})$ & 52 & 67 & 62 & 69 & 67 & 70
\end{tabular}

$11 \mathrm{mg}$ given intravenously at zero time.

weight were $121 \mathrm{~cm}$ and $24.4 \mathrm{~kg}$, respectively. The liver was palpable $17 \mathrm{~cm}$ below the costal margin in the right midclavicular line, $15 \mathrm{~cm}$ below the zyphoid, and $9 \mathrm{~cm}$ below the costal margin in the left midclavicular line. The spleen was not palpable. There were no xanthoma. Neurologic examination was negative.

Laboratory studies revealed the following: $\mathrm{Hb}$, $11 \mathrm{~g} / 100 \mathrm{ml}$; white blood count, 5000 ; blood $\mathrm{pH}, 7.22$; total plasma $\mathrm{CO}_{2}$ content, $8.3 \mathrm{~mm} / \mathrm{l}$; chloride, 100 $\mathrm{mEq} / \mathrm{l}$; sodium $147 \mathrm{mEq} / \mathrm{l}$; potassium, $4.8 \mathrm{mEq} / \mathrm{l}$; total serum lipids, $1924 \mathrm{mg} / 100 \mathrm{ml}$; free fatty acids, $1.4 \mathrm{mEq} / \mathrm{l}$; triglyceride lipids, $800 \mathrm{mg} / 100 \mathrm{ml}$; phospholipids, $600 \mathrm{mg} / 100 \mathrm{ml}$; and total cholesterol, 353 $\mathrm{mg} / 100 \mathrm{ml}$. Concentration of glycogen in erythrocytes was $131 \mu \mathrm{g} / \mathrm{g}$ hemoglobin. The results of an intravenous galactose tolerance test [30] and a two-hour postprandial glucagon stimulation test [13] are given in tables $\mathrm{I} a$ and $\mathrm{Ib}$ respectively.

Roentgenograms of the hands showed a significantly delayed bone age and diffuse demineralization.

\section{Methods}

Following admission, the patient was allowed activity as desired and was studied for four periods, the first and fourth being controls and the middle two while receiving a specific regimen. Protein, fat, and mineral 
Table IIa. Composition of diet (24-hour intake)

\begin{tabular}{|c|c|c|c|c|c|c|c|c|c|}
\hline \multirow[t]{4}{*}{ Period } & \multirow[t]{4}{*}{ Days } & \multirow{3}{*}{$\begin{array}{l}\text { Mixed } \\
\mathrm{CHO}^{1}\end{array}$} & \multicolumn{2}{|c|}{ Total CHO } & \multirow[t]{3}{*}{ Protein } & \multirow[t]{3}{*}{ Fat } & \multirow{4}{*}{$\begin{array}{c}\text { Calcium } \\
\mathrm{mEq}\end{array}$} & \multirow{4}{*}{$\begin{array}{c}\text { Phosphor- } \\
\text { ous } \\
\mathrm{mM}\end{array}$} & \multirow{4}{*}{$\begin{array}{c}\text { Total } \\
\text { calories }\end{array}$} \\
\hline & & & Supple & ments & & & & & \\
\hline & & & Sucrose & Glucose & & & & & \\
\hline & & \multicolumn{5}{|c|}{$g$} & & & \\
\hline Control & $1-6$ & 95 & $(240)^{2,3}$ & $(0)$ & 53 & 52 & $32.6(11.6)^{3}$ & $25(6)^{3}$ & 2070 \\
\hline Treatment period 1 & $7-10$ & 95 & $(0)$ & $(240)^{3}$ & 53 & 52 & $32.6(11.6)^{3}$ & $25(6)^{3}$ & 2070 \\
\hline Treatment period 2 & $10-15$ & 95 & $(0)$ & $(280)^{3}$ & 53 & 52 & $32.6(11.6)^{3}$ & $25(6)^{3}$ & 2230 \\
\hline Control & $16-21$ & 95 & $(240)^{2,3}$ & $(0)$ & 53 & 52 & $32.6(11.6)^{3}$ & $25(6)^{3}$ & 2070 \\
\hline
\end{tabular}

${ }^{1}$ Dietary starches in bread and cereal; fructose in fruit; lactose in milk. Monosaccharide content: glucose $68 \mathrm{~g}$; fructose $14 \mathrm{~g}$; galactose $13 \mathrm{~g}$.

${ }^{2}$ Monosaccharide content: glucose $120 \mathrm{~g}$; fructose $120 \mathrm{~g}$.

${ }^{3}$ Added to diet as a supplement.

Table IIb. Hexose content of the diet (24-hour intake)

\begin{tabular}{lcccc}
\hline Period & Days & $\begin{array}{c}\text { Glucose } \\
\mathrm{g}\end{array}$ & \multicolumn{2}{c}{ Fructose Galactose } \\
& & $\mathrm{g}$ & $\mathrm{g}$ \\
\hline $\begin{array}{c}\text { Control } \\
\text { Treatment } \\
\text { period 1 }\end{array}$ & $1-6$ & 188 & 134 & 13 \\
$\begin{array}{c}\text { Treatment } \\
\text { period 2 }\end{array}$ & $10-10$ & 308 & 14 & 13 \\
$\begin{array}{c}\text { Control } \\
15-21\end{array}$ & 348 & 14 & 13 \\
\hline
\end{tabular}

intakes were constant throughout the study periods (tables II a and II b). The diet contained $500 \mathrm{~g}$ of milk during both treatment and control periods. Dibasic calcium phosphate $\left(\mathrm{CaHPO}_{4} \cdot 2 \mathrm{H}_{2} \mathrm{O}\right) 0.5 \mathrm{~g}$ given twice a day added $11.6 \mathrm{mEq}$ of calcium and $6 \mathrm{mM}$ of phosphorus to the diet. The patient received 200 units of vitamin D in milk, plus 200 units of vitamin $D$ in a standard multivitamin preparation. During the control periods, he received a portion of the diet in midafternoon ( $200 \mathrm{~g}$ milk) and early evening ( $200 \mathrm{~g}$ milk), but no feedings were given after 9 p.m. The carbohydrate supplement, sucrose, was given with meals. During the experimental periods, he received the same total quantity of milk with meals, but glucose was substituted for sucrose in isocaloric quantities during Treatment Period No. 1 and in slightly greater quantities during Treatment Period No. 2. During the treatment periods, the diet was divided to assure that the patient received a minimum of $1 \mathrm{~g} / \mathrm{kg}$ of glucose every 3 hours. This was achieved by giving him $30 \mathrm{~g}$ (Treatment Period No. 1) or $35 \mathrm{~g}$ (Treatment Period No.2) of glucose in lemonade every 3 hours. Observations obtained during both treatment periods are combined.

In selecting the 'control' diet, an attempt was made to approach the previous home diet as closely as possible. In order to keep the protein, fat, and mineral intake constant, no complex carbohydrate was substituted for glucose during the control period during the night hours. Any similar but spontaneous increase in carbohydrate in the home diet would likely have been in the form of sucrose contained in pastries or candy. Sucrose was therefore used in order to maintain an isocaloric intake despite a potential for aggravating the organic acidosis as a result of the fructose content of sucrose [5,6].

Calcium was added because the dietary history suggested that the patient's calcium intake at home had been at the lower limits of normal for a child of his age [40]. The patient received the control diet for two days prior to initiation of the observations. No food was rejected nor were alkali supplements given during the study.

Following completion of the balance studies, the patient was discharged; an unrestricted diet supplemented by feedings of $1 \frac{1}{2} \mathrm{~g}$ glucose $/ \mathrm{kg}$ body weight at 3-hour intervals was prescribed. Supplemental calcium and vitamin D were not continued following completion of the balance studies. Reevaluation was made in the Out-Patient Department after 90 days and, again, after 210 days of the treatment program.

Blood samples for study were drawn prior to the 8 a.m. meal. Twenty-four urine specimens were collected hourly for 24 hours beginning at 7 a.m. and immediately refrigerated at $4^{\circ}$. An aliquot of each 24hour specimen was frozen at $-20^{\circ}$ until analyzed. Urine specimens for catecholamine determination 
were obtained by splitting each voiding and placing half of the specimen in a dark bottle containing $10 \mathrm{ml}$ $1 \mathrm{~N} \mathrm{HCl}$. Stool specimens were collected and refrigerated at $4^{\circ}$ until a 72 -hour collection was completed. Each complete collection was homogenized and analyzed. Results were reported in mean excretion per 24 hours. $\mathrm{Na}$ and $\mathrm{K}$ in the stool were measured by flame photometry and calcium by atomic absorption spectroscopy. Phosphorus was measured by the method of Fiske and Subba Row [8].

Levels of $\mathrm{Na}, \mathrm{K}, \mathrm{pH}$, and total bicarbonate in blood were analyzed as described previously [25]. Uric acid levels in serum were determined by reaction with alkaline phosphotungstate using the Technicon AutoAnalyzer method [10]. Phosphorus in serum was determined by the method of Fiske and Subba Row [8]. Glucose was determined by the glucose oxidase technique (Glucostat) and blood-reducing substances by the Somogyi-Nelson method [35]. Lactic acid was measured by an enzymatic method [32] and free fatty acids by ITAYA and Ur's modification of the Duncomb colorimetric method [15]. Cholesterol, triglycerides, and phospholipids in serum were measured by methods of Zurkowski [43], Jagannathan [16], and Henry [11], respectively. Erythrocyte glycogen was determined by the method described by SIDBuRY [31].

Urine $\mathrm{pH}$ was measured using a radiometer $\mathrm{pH}$ meter, and titratable acidity by titrating the urine to $\mathrm{pH}$ 7.4. Total urine $\mathrm{CO}_{2}$ was measured by the standard Van Slyke method [26], the bicarbonate content of urine was calculated by use of nomograms, and urine ammonia by the method of Bertholot as described by HenRy [11]. Calcium, sodium, potassium, and phosphorus in urine were determined as they were in stool. Organic acids were measured according to RELMAN [28]. Epinephrine and norepinephrine in urine were determined by von EULER's modification of the trihydroxyindole method [39] and vanilmandelic acid by the method of Pisano [27]. Urinary 17-OH corticosteroids were measured as Porter-Silber chromogens [33]. Growth hormone was determined by a modification of the radio-immunoassay method of BERSON and YALOW [17]; the standard used was Wilhelmi human growth hormone, HS 612B. The sensitivity of the method was $0.1 \mathrm{ng} / \mathrm{ml}$ serum. Metabolic data were plotted according to the convention of AlBRIGHT and Reifenstein [1].

\section{Results}

Data obtained during the control and treatment periods are listed in table III. During the control period, the patient demonstrated persistent hypoglycemia, hyperlacticacidemia, and metabolic acidosis. Despite severe acidosis, urinary $\mathrm{pH}$ did not fall below 5.5 units. During the treatment period, blood values returned toward normal. There was a profound decrease in net acid excretion associated with the correction of the acidosis. The decrease of both titratable acidity and ammonium excretion occurred within the first 24 hours and was associated with renal bicarbonate excretion. During the next five days, there was a constant rise in titratable acidity to levels approaching those occurring during the control period. The decrease in net acid excretion was accompanied by a decrease in organic acid excretion. The reduction of organic acid excretion during treatment was due to a decrease in lactic acid excretion (fig. 1). All findings reverted toward the original state with resumption of the control diet. Again, it was noted that despite significant acidosis, the urinary $\mathrm{pH}$ did not fall below 5.5. During the nine months of therapy, several measurements of total $\mathrm{CO}_{2}$ in plasma ranged between 22 and $24 \mathrm{mEq} / \mathrm{l}$ in first morning samples.

External calcium balances during three periods of study are shown in figure 2. A sharp fall in excretion of urinary calcium occurred within 24 hours following initiation of treatment (table III). Calcium balance, which was negative during the control period, became slightly positive and remained so throughout treatment. Fecal calcium remained relatively constant during all three periods. Blood calcium declined during treatment and returned to the previous concentration as acidosis recurred.

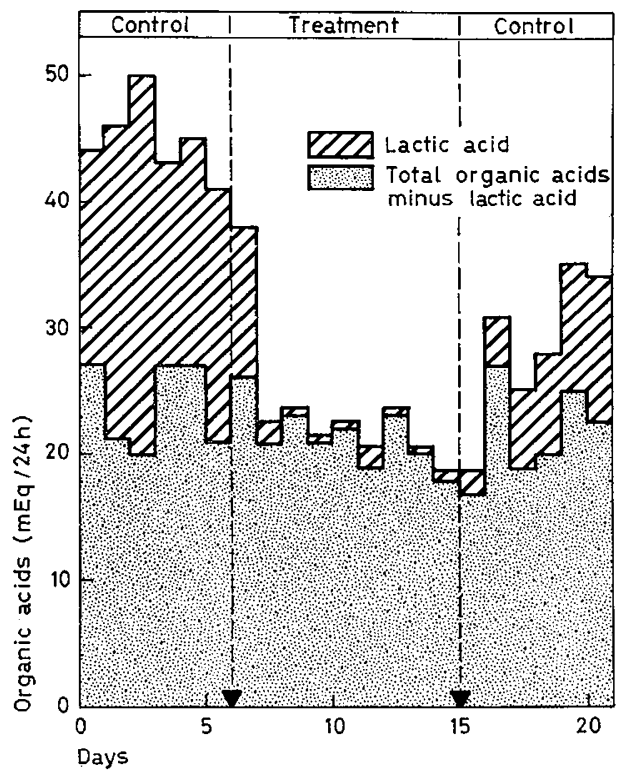

Fig. 1. Effect of frequent carbohydrate feeding on urinary excretion of organic acids. 
Table III. Metabolic effects

\begin{tabular}{|c|c|c|c|c|c|c|c|c|c|c|c|}
\hline \multirow{3}{*}{ Day } & \multirow{2}{*}{$\begin{array}{l}\text { Venous } \\
\text { Blood } \\
\text { pH }\end{array}$} & \multicolumn{6}{|c|}{ Plasma } & \multicolumn{2}{|c|}{ Blood } & \multirow[b]{2}{*}{$\mathrm{pH}$} & \multirow[b]{2}{*}{$\mathrm{HCO}_{3}$} \\
\hline & & $\begin{array}{r}\text { Total } \\
\mathrm{CO}_{2}\end{array}$ & $\mathrm{Na}$ & $\mathrm{K}$ & $\mathrm{Ca}$ & $P$ & $\begin{array}{l}\text { Uric } \\
\text { acid }\end{array}$ & Glu. & $\begin{array}{c}\text { Lac- } \\
\text { tate }\end{array}$ & & \\
\hline & & $\mathrm{mM} / \mathrm{l}$ & \multicolumn{2}{|c|}{$\mathrm{mEq} / \mathrm{l}$} & \multicolumn{5}{|c|}{$\mathrm{mg} / 100 \mathrm{ml}$} & & $\begin{array}{c}\mathrm{mM} / \\
\text { day }\end{array}$ \\
\hline \multicolumn{12}{|l|}{ Control } \\
\hline 1 & 7.26 & 9.5 & 146 & 5.8 & 10.0 & 4.0 & & 28 & 130 & 5.8 & 0.1 \\
\hline 2 & & & & & & & & & & 5.6 & 0.3 \\
\hline 3 & & & & & & & & & & 5.6 & 0.2 \\
\hline 4 & 7.26 & 10.4 & & & 10.5 & 4.7 & & 19 & 196 & 5.7 & 0.6 \\
\hline 5 & & & & & & & & & & 5.9 & 0.8 \\
\hline \multirow[t]{2}{*}{6} & 7.28 & 12.0 & 141 & 5.3 & 11.0 & 3.7 & 12.0 & 25 & & 5.9 & 1.3 \\
\hline & & & & & & & & \multicolumn{3}{|c|}{ Average: } & 0.5 \\
\hline
\end{tabular}

Treatment

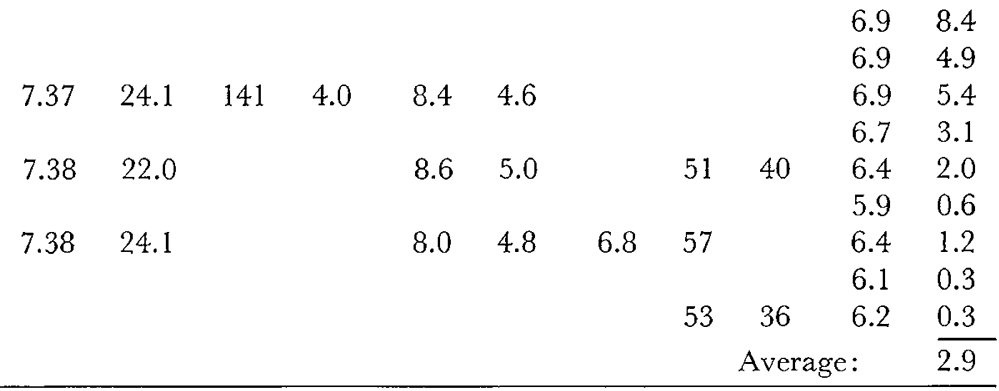

\section{Control}

16

17

18

19

20

21

\begin{tabular}{|c|c|c|c|c|c|c|c|c|c|c|}
\hline & & & & & & & & & 5.8 & 0.6 \\
\hline & & & & & & & 10 & & 6.1 & 1.0 \\
\hline \multirow[t]{2}{*}{7.27} & 14.7 & 144 & 5.2 & 10.5 & 5.1 & & 21 & 131 & 6.0 & 0.2 \\
\hline & & & & & & 115 & & & $\begin{array}{l}6.2 \\
6.1\end{array}$ & 0.8 \\
\hline \multirow[t]{2}{*}{7.26} & 12.7 & 144 & 5.1 & 10.0 & 4.1 & & & & 6.5 & 1.0 \\
\hline & & & & & & & & Avera & & 0.6 \\
\hline
\end{tabular}

${ }^{1}$ Onset treatment period 2. $\quad{ }^{2}$ Titratable acidity. $\quad{ }^{3} \mathrm{TA}+\mathrm{NH}_{4}-\mathrm{HCO}_{3}=$ net acid.

Urinary phosphorus excretion decreased slightly during treatment. Phosphorus balances were negative during the first control period $(-0.2 \mathrm{mM} /$ day $)$, became positive during treatment $(+2.9 / \mathrm{mM} /$ day $)$, and began to decrease during the final control period $(+1.0$ $\mathrm{mM} /$ day).

Roentgenograms of the bones obtained after 90 days of treatment showed broadened zones of provisional calcification in the distal tibia and fibula, as well as in the radius and ulna. The greater multangular bone of the right wrist had doubled in size.

Concentration of uric acid in blood fell sharply during treatment and returned to previous levels during the control period. A sudden increment in the daily excretion of uric acid occurred on the first day of treatment; a sharp decline occurred on the first day the patient returned to the control diet. After seven months of treatment at home, the level of uric acid in serum was $9.8 \mathrm{mg} / 100 \mathrm{ml}$.

During the first control period, the patient demonstrated hypercholesterolemia, hyperphospholipemia, and hyperglyceridemia (table IV). Five days after treatment was begun (day 11 , table IV), levels of all three lipid fractions had increased further; however, by the end of the treatment period, the triglyceride levels had decreased below the initial ones and the phospholipid levels were declining. Within 210 days, the total cholesterol and triglyceride levels had return- 
of frequent glucose feedings

\begin{tabular}{|c|c|c|c|c|c|c|c|c|c|c|c|c|c|c|}
\hline \multicolumn{11}{|c|}{ Urine } & \multicolumn{4}{|c|}{ Stool } \\
\hline $\mathrm{TA}^{2}$ & $\mathrm{NH}_{4}$ & $\begin{array}{l}\mathrm{Net}^{3} \\
\text { acid }\end{array}$ & $\begin{array}{l}\text { Organic } \\
\text { acids }\end{array}$ & $\begin{array}{c}\text { Lactic } \\
\text { acid }\end{array}$ & $\mathrm{K}$ & $\mathrm{Na}$ & $\mathrm{Ca}$ & $\mathrm{P}$ & $\begin{array}{l}\text { Greati- } \\
\text { nine }\end{array}$ & $\begin{array}{l}\text { Uric } \\
\text { acid }\end{array}$ & $\mathrm{Ca}$ & $\mathrm{Na}$ & $\mathrm{K}$ & $\mathrm{P}$ \\
\hline \multicolumn{8}{|c|}{$\mathrm{mEq} / 24 \mathrm{~h}$} & $\begin{array}{c}\mathrm{mM} / \\
\text { day }\end{array}$ & \multicolumn{2}{|c|}{$\mathrm{mg} / 24 \mathrm{~h}$} & \multicolumn{3}{|c|}{$\mathrm{mEq} /$ day } & $\begin{array}{c}\mathrm{mM} / \\
\text { day }\end{array}$ \\
\hline 21.5 & 63.9 & 85.3 & 44.1 & 17.3 & 27.6 & 57.0 & 25.8 & 25.0 & 563 & - & 32.2 & 1.8 & 7.0 & 12.7 \\
\hline 18.8 & 55.6 & 74.1 & 45.1 & 25.4 & 22.8 & 71.1 & 27.0 & 20.4 & 516 & - & 32.2 & 1.8 & 7.0 & 12.7 \\
\hline 23.3 & 56.9 & 80.0 & 49.1 & 29.5 & 25.5 & 84.7 & 27.5 & 22.9 & 496 & - & 32.2 & 1.8 & 7.0 & 12.7 \\
\hline 20.2 & 49.4 & 68.8 & 42.5 & 16.2 & 28.4 & 59.3 & 24.5 & 20.7 & 488 & 589 & 32.2 & 1.8 & 7.0 & 12.7 \\
\hline 19.2 & 49.8 & 68.2 & 44.3 & 17.6 & 26.0 & 70.9 & 25.1 & 20.8 & 498 & 530 & 32.2 & 1.8 & 7.0 & 12.7 \\
\hline 16.7 & 41.3 & 56.7 & 40.3 & 20.4 & 29.6 & 70.3 & 19.5 & 20.2 & 488 & 382 & 32.2 & 1.8 & 7.0 & 12.7 \\
\hline 19.9 & 52.8 & 72.2 & 44.1 & 21.0 & 26.6 & 68.8 & 24.8 & 21.6 & 508 & 500 & & & & \\
\hline 6.7 & 23.9 & 22.2 & 37.3 & 11.8 & 50.5 & 73.3 & 14.3 & 18.1 & 513 & 920 & 34.1 & 0.6 & 3.9 & 10.9 \\
\hline 5.3 & 22.1 & 22.5 & 23.1 & 2.1 & 30.6 & 87.4 & 11.5 & 14.9 & 470 & 676 & 34.1 & 0.6 & 3.9 & 10.9 \\
\hline 6.0 & 21.4 & 22.0 & 23.9 & 0.9 & 44.3 & 85.0 & 8.1 & 16.3 & 475 & 670 & 34.1 & 0.6 & 3.9 & 10.9 \\
\hline 9.1 & 20.2 & 26.2 & 21.3 & 1.2 & 49.5 & 73.9 & 8.1 & 19.3 & 496 & 603 & 34.1 & 0.6 & 3.9 & 10.9 \\
\hline 12.6 & 26.1 & 36.7 & 22.2 & 1.3 & 40.0 & 72.0 & 9.3 & 21.1 & 501 & 745 & 34.1 & 0.6 & 3.9 & 10.9 \\
\hline 15.2 & 29.2 & 43.8 & 20.5 & 2.0 & 34.6 & 79.0 & 9.4 & 21.7 & 519 & 500 & 34.1 & 0.6 & 3.9 & 10.9 \\
\hline 11.5 & 23.6 & 33.9 & 23.6 & 1.5 & 34.4 & 83.7 & 10.1 & 20.6 & 463 & 634 & 34.1 & 0.6 & 3.9 & 10.9 \\
\hline 13.5 & 24.7 & 37.9 & 20.4 & 0.4 & 33.7 & 87.5 & 11.3 & 20.2 & 466 & 620 & 34.1 & 0.6 & 3.9 & 10.9 \\
\hline 13.2 & 25.1 & 38.0 & 18.1 & 0.2 & 36.1 & 74.5 & 7.3 & 22.0 & 505 & 378 & 34.1 & 0.6 & 3.9 & 10.9 \\
\hline 10.3 & 24.0 & 31.4 & 23.3 & 2.4 & 39.3 & 79.5 & 9.8 & 19.3 & 490 & 638 & & & & \\
\hline 15.8 & 25.7 & 39.9 & 19.3 & 1.8 & 36.7 & 104.0 & 9.4 & 22.5 & 494 & 242 & 30.3 & 0.5 & 2.1 & 9.1 \\
\hline 21.2 & 34.6 & 54.8 & 30.3 & 4.1 & 45.1 & 76.1 & 13.4 & 32.3 & 538 & 574 & 30.3 & 0.5 & 2.1 & 9.1 \\
\hline 17.5 & 43.3 & 60.6 & 24.8 & 5.8 & 32.3 & 69.9 & 14.5 & 24.9 & 516 & 457 & 30.3 & 0.5 & 2.1 & 9.1 \\
\hline 14.4 & 42.1 & 55.7 & 28.1 & 7.5 & 33.3 & 80.0 & 14.5 & 22.0 & 486 & 623 & 30.3 & 0.5 & 2.1 & 9.1 \\
\hline 15.6 & 45.1 & 60.5 & 34.4 & 9.6 & 33.8 & 86.7 & 14.9 & 21.5 & 515 & 644 & 30.3 & 0.5 & 2.1 & 9.1 \\
\hline 11.0 & 39.8 & 49.8 & 33.9 & 11.2 & 35.3 & 95.2 & 15.9 & 21.1 & 509 & 645 & 30.3 & 0.5 & 2.1 & 9.1 \\
\hline 15.9 & 38.5 & 53.5 & 28.5 & 6.6 & 36.2 & 85.3 & 13.8 & 24.0 & 510 & $\overline{531}$ & & & & \\
\hline
\end{tabular}

ed to normal concentrations, but those of the phospholipids remained elevated.

The excretion of epinephrine, norepinephrine, and vanilmandelic acid in urine was measured daily during the last three days of each period. Levels were similar; the average values are shown in table $\mathrm{V}$.

The excretion of 17-OH corticosteriods in urine over a 24-hour period was measured on two consecutive days during each period. There was no difference between the control $(2.6 \mathrm{mg} / 24 \mathrm{~h})$ and the treatment $(2.3 \mathrm{mg} / 24 \mathrm{~h})$ periods.

Concentrations of growth hormone and glucose, the latter shown in parenthesis, measured in serum drawn at 8 a.m. on days 1,15 , and 17 were $1.9 \mathrm{ng} / \mathrm{ml}$
(28 mg/100 ml), $0.9 \mathrm{ng} / \mathrm{ml}(53 \mathrm{mg} / 100 \mathrm{ml})$, and 1.7 $\mathrm{ng} / \mathrm{ml}(10 \mathrm{mg} / 100 \mathrm{ml})$, respectively [44]. Samples on days 1 and 17 were taken after a 12-hour fast. The sample on day 15 was taken 3 hours after the patient had received $35 \mathrm{~g}$ of glucose. Four months after continuous use of the prescribed diet, growth hormone level 3 hours after a glucose feeding was $0.6 \mathrm{ng} / \mathrm{ml}$, when the glucose level in blood was $34 \mathrm{mg} / 100 \mathrm{ml}$. Following continuous use of the diet for six months, a sample of blood taken 5 hours after a glucose feeding contained $2 \mathrm{ng} / \mathrm{ml}$ of growth hormone at a time when the glucose level was $12 \mathrm{mg} / 100 \mathrm{ml}$. The patient was experiencing symptoms suggesting hypoglycemia at the time this latter sample was obtained. After nine 


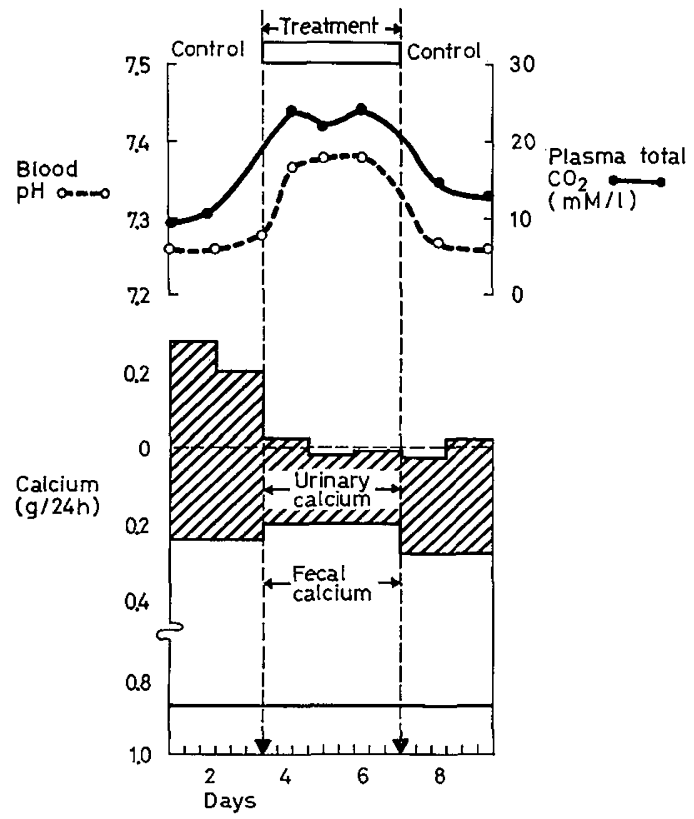

Fig. 2. Effect of frequent carbohydrate feeding on the external calcium balance in hepato-renal glycogenosis. Calcium intake $(0.89 \mathrm{~g} /$ day $)$ is plotted from base line downward; excretion is plotted from the intake line upward.

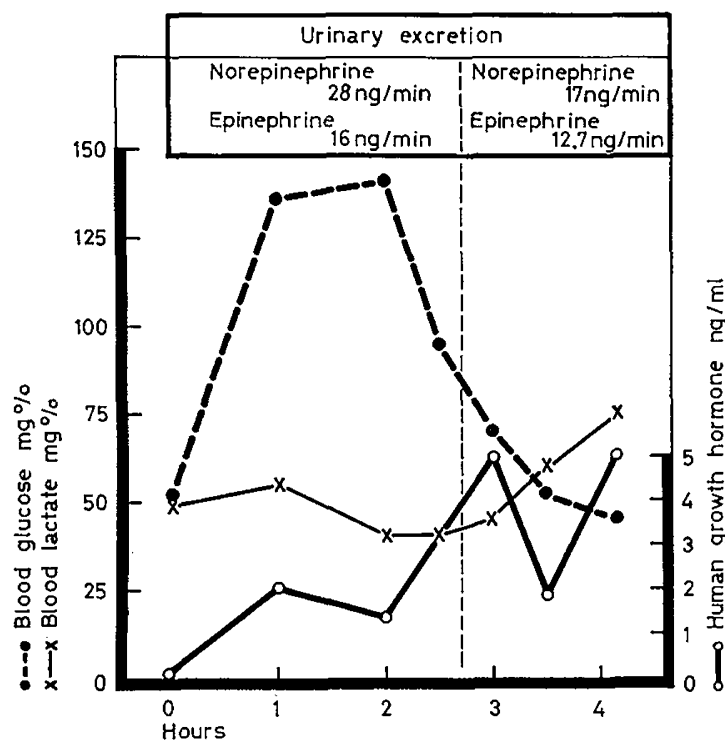

Fig. 3. The response of growth hormone concentration in serum and urinary excretion of catecholamines to an oral glucose load (1.5 g glucose $/ \mathrm{kg}$ body weight at 0 time) after nine months of frequent carbohydrate feedings.
Table IV. Effect of frequent glucose feeding on the serum lipid concentrations

\begin{tabular}{lccccc}
\hline Period & Control & \multicolumn{4}{c}{ Treatment } \\
Day & 1 & 11 & 15 & 90 & 210 \\
\hline $\begin{array}{c}\text { Cholesterol } \\
\quad(\mathrm{mg} / 100 \mathrm{ml})\end{array}$ & 353 & 468 & 452 & 230 & 219 \\
$\begin{array}{c}\text { Phospholipids } \\
(\mathrm{mg} / 100 \mathrm{ml})\end{array}$ & 600 & 812 & 590 & & 430 \\
$\begin{array}{c}\text { Triglycerides } \\
(\mathrm{mg} / 100 \mathrm{ml})\end{array}$ & 800 & 1100 & 550 & 206 & 97 \\
\hline
\end{tabular}

Table V. Catecholamine excretion during dietary treatment

\begin{tabular}{|c|c|c|c|}
\hline & $\begin{array}{c}\mathrm{A}^{1} \\
\mathrm{ng} / \mathrm{mgCr}^{2}\end{array}$ & $\begin{array}{c}\mathrm{NA}^{3} \\
\mathrm{ng} / \mathrm{mgCr}^{2}\end{array}$ & $\begin{array}{c}\mathrm{VMA}^{4} \\
\mu \mathrm{g} / \mathrm{mgCr}^{2}\end{array}$ \\
\hline Control 1 & 9.6 & 29.2 & 5.2 \\
\hline Treatment & 13.8 & 29.7 & 4.9 \\
\hline Control 2 & 7.8 & 28.5 & 5.2 \\
\hline Normal values ${ }^{5}$ & $7.4 \pm 6.1$ & $25.3 \pm 3.1$ & $4.9 \pm 0.7$ \\
\hline \multicolumn{4}{|c|}{$\begin{array}{l}{ }^{1} \mathrm{~A}=\text { epinephrine. } \\
{ }^{2} \mathrm{Cr}=\text { creatinine. } \\
{ }^{3} \mathrm{NA}=\text { norepinephrine. } \\
{ }^{4} \mathrm{VMA}=\text { vanilmandelic acid. } \\
{ }^{5} \mathrm{Mean} \pm \mathrm{SD} \text { for children by our laboratory. }\end{array}$} \\
\hline
\end{tabular}

Table VI. Changes in levels of growth hormone, glucose, and lactate in blood in response to glucose load after nine months of frequent carbohydrate feedings

\begin{tabular}{lcccccccc}
\hline Time $(\mathrm{h})$ & 0 & 1 & 2 & $2 \frac{1}{2}$ & 3 & $31 / 2$ & 4 \\
\hline $\begin{array}{l}\text { Growth } \\
\text { hormone } \\
(\mathrm{ng} / \mathrm{ml})\end{array}$ & 1.6 & 2.0 & 1.6 & 1.7 & 5.0 & 1.6 & 5.0 \\
\hline $\begin{array}{l}\text { Glucose } \\
(\mathrm{mg} / 100 \mathrm{ml})\end{array}$ & 52 & 137 & 140 & 96 & 72 & 53 & 46
\end{tabular}

Lactate

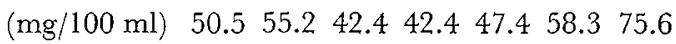


months on the diet, the patient was again studied. After fasting for 3 hours, he received glucose $\left(1 \frac{1}{2} \mathrm{~g} / \mathrm{kg}\right)$ by mouth. Following this, the growth hormone response to the spontaneous fall in blood sugar was observed for 4 hours. After 4 hours, the patient became restless and confused. The symptoms were attributed to the presence of hypoglycemia and the test was terminated. The results of that test are shown in figure 3. The data indicate that the levels of growth hormone were elevated when a rapid fall in blood glucose occurred. Gatecholamine excretions were not increased during the test.

Figure 4 illustrates the improved growth of the patient following the initiation of frequent glucose feedings.

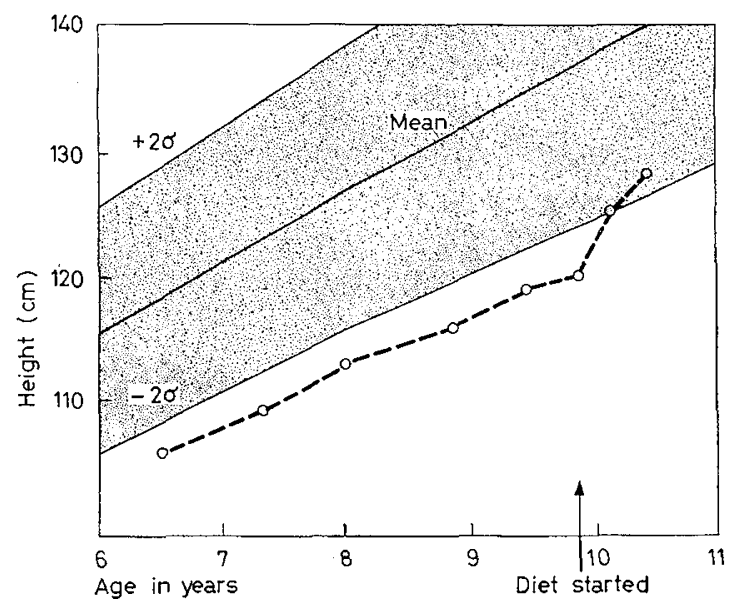

Fig. 4. Effect of frequent carbohydrate feeding on linear growth of a patient with hepatorenal glycogenosis.

\section{Discussion}

The defect in glycogen metabolism in this patient was not proved by enzymatic methods. The clinical picture of massive hepatomegaly, dwarfism, and hypoglycemia is consistent with the diagnosis of a glycogenosis. A deficiency of amylo 1,6 glycosidase would have been expected to cause an elevation in erythrocyte glycogen content [31], a rise in the concentration of blood glucose following the 2-hour postprandial glucagon stimulation test [13], and a normal intravenous galactose tolerance test [30]. Liver phosphorylase deficiency appears to be a milder clinical disease than that presented by this patient; in addition, his condition was unassociated with the abnormality found in patients with phosphorylase deficiency following infusion of galactose $[5,18,37]$. The abnormal glucagon and intravenous galactose tolerance tests strongly suggest a deficiency in glucose-6-phosphatase activity.

The data support the value of frequent glucose feedings in correcting the metabolic acidosis of this form of glycogen storage disease. They do not exclude the possibility that the fructose ingested as sucrose during the control periods may have aggravated the lactate retention and that some of the improvement noted in this patient during frequent glucose feeding was secondary to the withdrawal of fructose [5]. There are no data available that describe the extent to which lactate is accumulated when glucose and fructose are given simultaneously, such as occurs when sucrose is ingested. In this patient, the significant contribution of lactic acid in the production of metabolic acidosis $[21,22,34]$ during the control periods was indicated by the accumulation of $21 \mathrm{mEq} / \mathrm{l}$ of lactate in the blood by the fourth day. The source of this lactate during the fasting state appeared to be due to hepatic glycolysis, indicated by the greater concentration of lactate in arterial blood than in venous blood [12, 22]. The stimulus to this glycolysis is postulated to be peripheral hypoglycemia and may be mediated by either glucagon or epinephrine. SoKal et al. [34] have presented indirect evidence that glucagon, not epinephrine, is the mediator of this effect. Since serial blood samples reflect the immediate metabolic status, not the undulating changes likely to occur throughout 24-hour periods [5], comparing daily urinary measurements may reflect a more accurate net balance achieved by frequent glucose feeding. It is probable that lactate accumulated, but not excreted, in urine throughout the fasting portions of the control periods was at least partially metabolized during the day when adequate peripheral glucose concentrations from sucrose and complex carbohydrates inhibited the stimuli to glycolysis. This could have resulted in some restoration of the buffers during the nonfasting state. This concept is supported by the rapid decline in urinary net acid excretion accompanied by the loss of bicarbonate in the urine on the first treatment day. During treatment, the patient did not have a positive qualitative test for urinary ketones. Since the difference in the organic aciduria that occurred during the control and treatment periods was probably the result of lacticaciduria, urinary ketone bodies could not have contributed significantly to the organic aciduria in this patient. The degree of ketonuria is known to be variable in patients with glucose-6-phosphatase deficiency, and severe acidosis can occur without acetonuria [6].

The patient studied appeared to have an inadequate renal response to an acid load, indicated by a urinary $\mathrm{pH}$ that did not fall below 5.6, despite an apparent relatively constant state of metabolic acidosis. Evidence to support the presence of this defect would be 
stronger if frequent blood samples had been obtained throughout the day to prove the persistence of the acidotic state. Evaluation of the patient after eight months of dietary therapy indicated the ability to produce a urine of $\mathrm{pH} 4.5$ after a 3 -hour fast. Transient defects in acidification have been described in metabolic diseases associated with potassium deficiency [23], galactosemia [14], and vitamin D deficiency [41]; the mechanisms are probably multiple. Further studies are needed to confirm the presence of such defects in patients with glycogenosis.

It has been generally believed that the major effect of metabolic acidosis on calcium metabolism is an increased loss of calcium in urine. More recently, reported evidence has implicated the gastrointestinal tract as an important route of calcium loss in the metabolic acidosis of uremia [36] and in renal tubular acidosis [9]. Most studies of this problem have required production of metabolic acidosis after ingestion of ammonium chloride or correction of a chronic acidosis by ingestion of citrate or bicarbonate. The present patient presented an opportunity to study external calcium balance during the correction of acidosis without the use of alkalinizing salts. Figure 2 compares external calcium balance to acidosis. In this patient, it is apparent that metabolic acidosis affected most the urinary excretion of calcium and that fecal excretion actually increased during correction of the acidosis. Calculation of the ratios of calcium: creatinine excreted daily and comparison of these values with the normal values described by NoRdin [24] indicate that although significant correction of urinary calcium losses occurred, normal levels were not reached during treatment. The large negative balance of calcium exhibited at the onset of the study probably represented acute bone depletion secondary to increasing acidosis [19]. This may have been the result of the discontinuation of alkalizing salts, the addition of fructose to the diet as sucrose, or the institution of fixed feeding periods, since prior to the study, the patient usually ate before 8 a.m. and as late as 11 p.m.

This study fails to explain the fall in calcium levels in serum during correction of the acidotic state. The reduction, in the presence of increasing retention of calcium, suggests increasing deposition of calcium at some site, probably bone. The studies by LEMANN $e t$ al . [19] on the effect of ammonium chloride acidosis on calcium and phosphate metabolism did not show a similar fall during the correction of acidosis.

During treatment, levels of urate in blood could be controlled by frequent glucose feeding. The elevation of uric acid in blood found in patients with glycogenosis has been attributed to a competitive inhibition of renal tubular uric acid secretion by lactate [7], $\beta$-hydroxybutyric acid [2], and increased synthesis of uric acid [2]. Despite continuous use of the diet for nine months at home while the activity of the patient was unrestricted, urate concentrations in blood were continued at levels between 9 and $10 \mathrm{mg} / 100 \mathrm{mg} /$ $100 \mathrm{ml}$. These probably reflected the abnormal level of lactate, $40 \mathrm{mg} / 100 \mathrm{ml}$, the patient maintained while at home.

The etiology of hyperlipemia associated with glucose-6-phosphatase deficiency is unknown. Hypoglycemia results in mobilization of free fatty acids and increased synthesis of lipids secondary to the augmented production of TPNH and glycerol [20]. Increased elevation of serum lipids on the eleventh day of the treatment period, in comparison with the initial values (table IV), may be an example of carbohydrateinduced hyperlipemia [3], since both control and treatment diets contained more carbohydrate than was usually ingested by the patient at home. The steady decline of the triglyceride and cholesterol levels (days 90 and 210) indicates the effectiveness of frequent glucose feedings in controlling the hyperlipemia of this form of glycogenosis. The persistent elevation of the phospholipids cannot be explained. During treatment, the liver decreased considerably in size. This decrease may have been due to a reduction in fatty infiltration [20], since it seems improbable that frequent glucose feedings would decrease glycogen accumulation in liver.

It was expected that the excretion of epinephrine in urine would increase in response to the hypoglycemia. No increase was noted. Such a response has been demonstrated by BROBERGER and ZETTERSTROM [4] following insulin tolerance tests in normal children. If a response of the magnitude seen by these investigators had been present in our patient, it should have been evident even in the 24-hour collection periods. That the hypoglycemia was metabolically significant is substantiated by the increased levels of growth hormone and lactate in plasma.

The lack of increased urinary excretion of $17-\mathrm{OH}$ corticosteroids during both control and treatment periods was surprising and may indicate that this patient did not have a significant cortisol response to hypoglycemia.

The concentrations of growth hormone in serum observed in this patient during the initial studies indicated an inadequate response to hypoglycemia. The persistently low levels of growth hormone associated with severe hypoglycemia following fasts of varying duration prompted the evaluation of the effect of a rapid decline of blood sugar on growth hormone concentration after nine months of dietary therapy (fig. 3). The data demonstrate that at the time of this test, the patient was able to respond to developing hypoglycemia with a significant rise in growth hormone levels 
in serum. It is known that concentrations of growth hormone undergo considerable fluctuation during a 24-hour period in children [29], but there are no data indicating that the consistently low levels demonstrated in this patient in the presence of severe hypoglycemia could be a manifestation of sampling. The low levels of growth hormone observed during the initial studies possibly reflect depletion of growth hormone.

During the nine months that this patient remained on a regimen with frequent glucose feeding, it became apparent that hewas much more susceptible tosymptomatic hypoglycemia than he had been prior to the initiation of the diet. Before dietary therapy his mental processes were normal despite hypoglycemia tor below $10 \mathrm{mg} / 100$ $\mathrm{ml}$ maintained for several hours. After nine months of therapy, a delay in feeding for only 30-60 minutes could precipitate hypoglycemia and disturbed consciousness. This suggests that treatment should be initiated with caution, with rigorous adherence to the program once initiated, particularly during the night hours.

\section{References and Notes}

1. Albright, F. and Reifenstein, E.C., Jr.: The parathyroid glands and metabolic bone disease, p. 309 (Williams and Wilkins, Baltimore 1948).

2. Alepa, F.P.; Howeld, R.R.; Klunenberg, J.R. and Seegmiller, J.E.: Relationship between glycogen storage disease and tophaceous gout. Amer. J. Med. 42: 58 (1967).

3. Anderson, J.T.: Dietary carbohydrate and serum triglycerides. Amer. J. clin. Nutr. 20: 168 (1967).

4. Broberger, O. and Zetrerstrom, R.: Hypoglycemia with inability to increase the epinephrine secretion in insulin-induced hypoglycemia. J. Pediat. 59: 215 (1961).

5. Fernandes, J. and van de Kamer, J.H.: Studies on the utilization of hexoses in liver glycogen disease. Pediatrics 35: 470 (1965).

6. FIELD, R.A.: Glycogen deposition disease, in The metabolic basis of inherited disease (ed. STANBURY, J.B.; Wyngaarden, J.B. and Fredrickson, D. S.) (McGraw-Hill, New York 1966).

7. Fine, R. N.; Strauss, J. and Donnell, G. N.: Hyperuricemia in glycogen storage disease type I. Amer. J. Dis. Child. 112: 572 (1966).

8. Fiske, C.H. and SubBa Row, T.: The colorimetric determination of phosphorus. J. biol. Chem. 66: 375 (1925).

9. Greenberg, A.J.; McNamara, H. and McCrory, W.W.: Metabolic balance studies in primary renal tubular acidosis: Effects of acidosis on external calcium and phosphorus balances. J.Pediat. 69: 610 (1966).
10. Hawk's physiological chemistry (ed. Oser, B. L.), 14th ed., p. 1046 (McGraw-Hill Book, New York 1965).

11. Henry, R.J.: Clinical chemistry: Principles and technics, p. 329 (Harper and Row, New York 1965).

12. Howell, R. R.; Ahston, D. M. and WyngaARden, J.B.: Glucose-6-phosphatase deficiency glycogen storage disease. Pediatrics 29: 553 (1962).

13. Hug, G.: Glucagon tolerance test in glycogen storage disease. J. Pediat. 60: 545 (1962).

14. Huth, E.J.; Webster, G.D., Jr. and Elkinton, J.R.: The renal excretion of hydrogen ion in renal tubular acidosis. III. An attempt to detect latent cases in a family: comments on nosology, genetics and etiology of the primary disease. Amer.J. Med. 29: 586 (1960).

15. ITAXA, K. and UI, M. : Colorimetric determination of free fatty acids in biological fluids. J. Lipid Res. 6: 16 (1965).

16. JaGANNATHAN, S.N.: The determination of plasma triglycerides. Canad.J. Biochem. 42: 566 (1964).

17. KNoller, M.; Tsao, M.U. and Lowrey, G.H.: Radio-immunoassay of human growth hormones. Clin. Chem. 14: 145 (1968).

18. Lamy, M.; Dubots, R.; Rossier, A.; Frézal, J.; Loeb, H. et Blancher, G.: La glycogénose par déficience en phosphorylase hépatique. Arch. franç. Pédiat. 17: 14 (1960).

19. Lemann, J., Jr.; Lirzow, J.R. and Lennon, E. J. : The effects of chronic acid loads in normal man: Further evidence for participation of bone mineral in the defense against chronic metabolic acidosis. J. clin. Invest. 45: 1608 (1966).

20. Lowe, G. U.; Sokal, J.E.; Mosovich, L.L.; SARCione, E.J. and Doray, B.H.: Studies in liver glycogen disease: Effects of glucagon and other agents on metabolic pattern and clinical status. Amer.J. Med. 33: 4 (1962).

21. MASON, H.N. and SLY, G.E.: Blood lactic acid in liver glycogen disease. Proc. Soc. exp. Biol., N.Y. 53: 145 (1943).

22. Mason, H.H. and Andersen, D.H.: Glycogen disease of the liver (Von Gierke's disease) with hepatomata: Case report with metabolic studies. Pediatrics 16: 785 (1955).

23. Milne, M.D.; Muerhrche, R.G. and Heard, B.E.: Potassium deficiency and the kidney. Brit. med. Bull. 13: 15 (1957).

24. Nordin, B.E.C. and Smith, D.A.: Diagnostic procedures in disorders of calcium metabolism, p. 22 (Churchill, London 1965).

25. Olrver, W.J.: Physiologic responses associated with steroid induced diuresis in the nephrotic syndrome. J. Lab. clin. Med. 62: 449 (1963).

26. Peters, J.P. and VAN SLyke, D.D. : Quantitative 
clinical chemistry, vol.II, p.290 (Williams and Wilkins, Baltimore 1932).

27. Pisano, J.J.; Grout, J.R. and Abraham, D. : Determination of 3-methoxy-4-hydroxymandelic acid in urine. Clin. chim. Acta 7: 285 (1962).

28. Relman, A. S.; Lennon, E.J. and Lemann, J., Jr.: Endogenous production of fixed acid and the measurement of the net balance of acid in normal subjects. J. clin. Invest. 40: 1621 (1961).

29. Rigal, W. M. and Hunter, W. M.: Sites and mode of action of growth hormone; in Calcified tissues. Proceedings of the Third European Symposium, 1965 (Springer, New York 1966).

30. Schwartz, R.; Ashmore, J. and Renold, A.E.: Galactose tolerance in glycogen storage disease. Pediatrics 19: 585 (1957).

31. Sidbury, J.B.; Cornblath, M.; Fisher, J. and House, E.: Glycogen in erythrocytes of patients with glycogen storage disease. Pediatrics 27: 103 (1961).

32. Sigma Technical Bulletin No.825-UV.

33. Silber, R.H. and Porter, G. C.: Determination of 17,21-dihydroxy-20 keto steroids in urine and plasma. Meth. Biochem. Anal. IV: 139 (1957).

34. Sokal, J. E.; Lowe, C. U.; Sarcione, E.J.; MosoVICH, L.L. and DoRAy, B.H.: Studies of glycogen metabolism in liver glycogen disease (von Gierke's disease). Six cases with similar metabolic abnormalities and responses to glucagon. J.clin. Invest. 40: 364 (1961).

35. Somogyi, M.: A new reagent for the determination of sugars. J. biol. Chem. 160: 61 (1945).

36. Stanbury, S.W. and Lumb, G.A.: Metabolic studies of renal osteodystrophy. Medicine, Baltimore 41: 1 (1962).

37. Van Greveld, S.: The clinical course of glycogen disease. Ganad. med. Ass. J. 88: 1 (1963).

38. Van Greveld, S. and Huijing, F.: Glycogen storage disease: Biochemical and clinical data in sixteen cases. Amer. J. Med. 38: 554 (1965).

39. Von Euler, U.S. and Lishajko, F.: Improved technique for the fluorimetric estimation of catecholamines. Acta physiol. scand. 51: 348 (1961).

40. WANG, G. C.; Kern, R. and Kavgaher, M. : Minimum requirement of calcium and phosphorus in children. Amer. J. Dis. Ghild. 39: 768 (1930).

41. Whrrten, C.F.: The defect in renal acidification in vitamin $\mathrm{D}$ deficiency rickets. J.Pediat. 69: 80 (1966).

42. WyngaArden, J.B.: Advances in metabolic disorders (ed. Levine, R. and Luft, R.), vol. 2, p.60 (Academic Press, New York 1965).

43. Zurkowski, P.: A rapid method for cholesterol determination with a single reagent. Clin. Chem. 10: 451 (1964).

44. Growth hormone determinations were done in the laboratory of Dr. George Lowrey. Range of normal fasting growth hormone levels in that laboratory ages 2 to 17 are $0.2-18 \mathrm{ng} / \mathrm{ml}$, with a median of 1.6 and a mean of 3.1. All normal patients were normoglycemic.

45. A preliminary report of a portion of these data was published in the Abstracts of the Society for Pediatric Research for the Annual Meeting (1967).

46. The authors acknowledge the technical assistance of T. Moses and L.VADNAY.

47. This work was supported by a research grant from the Michigan Kidney Disease Foundation and in part by Research Grant 08381-5M01 FR-42-07, from the National Institutes of Health, United States Public Health Service.

48. Requests for reprints should be addressed to: RoBerT C. Kelsch, M.D., Department of Pediatrics and Communicable Diseases, University of Michigan Medical Genter, Ann Arbor, Mich. 98104 (USA). 